\title{
PERAN DISPORAPAR KABUPATEN KUNINGAN DALAM MENINGKATKAN OLAHRAGA PRESTASI DI KABUPATEN KUNINGAN
}

\author{
Nanang Mulyana \\ STKIP Muhammadiyah Kuningan \\ email: nanangmulyana@gmail.com
}

\section{Info Artikel}

Sejarah Artikel:

Diterima Desember 2017

Disetujui Desember 2017

Dipublikasikan Januari 2018

Keywords:

Kebijakan, pembinaan, SDM, Koordinasi

\begin{abstract}
Abstrak
Penelitian ini dimaksudkan untuk mendeskripsikan Peran Dinas Pemuda Olahraga dan Pariwisata dalam peningkatan prestasi olahraga di Kabupaten Kuningan. Metode pengumpulan data dalam penelitian ini adalah observasi, wawancara dan dokumentasi. Prestasi olahraga dapat diraih, jika dilakukan pembinaan yang baik dan benar, yaitu dilakukan secara terarah, terpadu dan berjenjang dari pemassalan, pemanduan bakat, pembibitan serta pembinaan lanjutan. Setelah dilakukan penelitian, ditemukan faktor-faktor yang mengakibatkan kenapa pembinaan yang dilakukan kurang maksimal. Faktor pendukung adalah adanya kebijakan Pemerintah, potensi yang dimiliki daerah serta adanya kerjasama. Sedangkan faktor penghambatnya adalah sistem birokrasi yang bertangga, rendahnya kualitas sumber daya manusia (SDM), minimnya sarana dan prasarana yang ada serta kurangnya finansial.
\end{abstract}

\begin{abstract}
This study was intended to describe the role of the Youth and Sports Department of Tourism in improving sports performance in Kuningan Regency. Data collection methods in this study are observation, interviews and documentation. Sports achievements can be achieved, if good and right guidance is carried out, namely carried out in a directed, integrated and tiered manner of observation, talent scouting, nursery and further guidance. After doing the research, found factors that led to why the training carried out was not optimal. Supporting factors are the existence of Government policies, the potential of the region and the existence of cooperation. Whereas the inhibiting factor is a proud bureaucratic system, low quality of human resources (HR), lack of existing facilities and infrastructure and lack of financial.
\end{abstract}

(C) 2019 Nanang Mulyana

Under the license CC BY-SA 4.0

ISSN 2443-1117 (cetak)

\footnotetext{
$凶$ Alamat korespondensi:

nanangmulyana@gmail.com

$\begin{array}{ll}\text { E-mail } & \text { : nanangmulyana } \\ \text { No Handphone : } 081322424899\end{array}$
} 


\section{PENDAHULUAN}

Olahraga tidak hanya sebagai kebutuhan untuk menjaga kebugaran tubuh, akan tetapi olahraga telah merasuk dalam semua sektor kehidupan. Lebih jauh lagi, prestasi olahraga dapat mengangkat harkat dan martabat manusia baik secara individu, kelompok, masyarakat, bangsa, dan negara.

Suatu prestasi olahraga tidak serta merta datang dengan sendirinya. Hal ini tidak semua orang bisa memahami, bahkan mereka hanya berorientasi pada hasil kompetisi atau kejuaraan yang di tandai dengan perolehan medali, tanpa memperhatikan proses dari pembinaan yang dimulai dari usia dini. Oleh karena itu, diperlukan kerjasama dengan lembagalembaga pengembangan IPTEK olahraga, untuk memberikan jawaban yang ilmiah dan nyata bahwa prestasi merupakan hasil dari proses latihan dan pengembangan bakat.

Penataan olahraga prestasi harus dimulai dari pemassalan diharapkan akan memunculkan bibit-bibit atlit. Sebagai langkah berikutnya perlu melakukan kerja sama antara Pemerintah dengan induk organisasi keolahragaan seperti Komite Olahraga Nasional Indonesia (KONI).

Kompleksitas pembinaan dan pengembangan yang ada, maka Dinas Pemuda Olahraga dan Pariwisata (DISPORAPAR) Kabupaten Kuningan yang diberikan tugas dan tanggung jawab menangani keolahragaan diharapkan lebih aktif menjalankan perannya baik dalam membuat kebijakan maupun pada pelaksanaan, sehingga mampu mendekatkan jarak antara pemegang kebijakan dengan pelaku di lapangan seperti guru, pelatih dan pembina olahraga.

\section{METODE PENELITIAN}

Metode penelitian adalah usaha untuk menemukan, mengembangkan, dan menguji kebenaran suatu pengetahuan, yang dilakukan dengan metode-metode ilmiah.

Jenis penelitian yang pergunakan dalam penelitian ini adalah penelitian diskriptif. Penelitian deskriptif adalah usaha mengungkapkan suatu masalah atau keadaan atau peristiwa sebagaimana adanya, sehingga bersifat sekunder untuk mengungkapkan fakta.

1. Teknik Pengumpulan Data

Sebagai upaya pengumpulan data dalam penelitian ini, diperlukan teknik dan alat pengumpul data sebagai berikut

Teknik Observasi, melakukan pengumpulan data secara langsung dan dilakukan secara terbatas mengenai aktifitas dari objek yang diteliti, kami melakukan observasi terhadap kegiatan yang dilakukan oleh Dinas Pemuda Olahraga dan Pariwisata yang berkenaan dengan prestasi olahhraga.

Teknik Wawancar, teknik ini merupakan upaya pengumpulan data yang dihimpun dari responden atau informan yang akan dimintai informasi. Dalam hal kami mewawancarai pihak terkait dalam hal para informan yang kompeten baik langsung maupun tidak langsung.

Studi Dokumentasi, dokumentasi yaitu cara pengumpulan data yang dilakukan dengan mempelajari buku-buku, literature dan dokumen-dokumen yang erat hubungannya dengan materi penelitian. Hal ini diupaya untuk mensinkronkan antara teori dan realita di lapangan.

\section{Teknik Analisis Data}

Analisis data didahului dengan menghimpun dan mengumpulkan data atau informasi di lapangan sebagai berikut :

a. Pengumpulan Data

Sebagai konsep dasar langkah-
langkah yang dilakukan dalam
menganalisis data, pertama-tama
mengorganisasikan data. Data yang
terkumpul terdiri dari catan lapangan,
komentar subyek penelitian, dokumen
berupa laporan dan sebagainya.
b. Reduksi Data

Reduksi data merupakan suatu kegiatan proses penghalusan atau pemilihan data yang diperoleh di lapangan, proses tersebut untuk lebih menyederhanakan data yang diperoleh dengan memberi kode, mengklasifikasi, menelusuri dengan tematema, membuat gugus, menulis memo dan 
memilah bagian-bagian yang tidak tidak relevan dengan fokus penelitian.

\section{c. Penyajian Data}

Penyajian data adalah dilakukan setelah kegiatan reduksi, kemudian data tersebut disajikan menjadi kumpulan informasi tersebut dapat ditarik kesimpulan sementara yang akan diuji lebih lanjut untuk mendapatkan hasil yang diinginkan.

3. Penarikan Kesimpulan

Penarikan kesimpulan merupakan langkah terakhir dari suatu analisis data yang berusaha mencari arti terhadap data yang disajikan dan berusaha menghubungkan data dengan gejala sosial lainnya.

\section{HASIL DAN PEMBAHASAN}

Pembinaan dan pengembangan olahraga yang di mulai anak usia dini atau usia sekolah sebagai langkah awal pembinaan mengarah pada pembinaan prestasi. Hal ini tentu tidak terlepas dari sistem pembinaan, tenaga keolahragaan, sarana prasarana dan pendanaan.

1. Peran Dinas Pemuda Olahraga dan Pariwisata dalam Sistem Pembinaan Keolahragaan

Sistem pembinaan keolahragaan pada umumnya menganut dua hal yakni sistem pembinaan olahraga yang menonjolkan pada olahraga elit (Elit Sport) dan pembinaan olahraga yang memfokuskan pada budaya gerak (sport and movement culture). Olahraga elit dicirikan adanya kompetisi dan maksimalisasi prestasi. Kemenangan merupakan sesuatu yang di agungkan, apapun bentuknya. Dampak negatif yang ada seperti penggunaan obat perangsang (doping), eklsploitasi fisik dan kekerasan.

Medali secara faktual memang merupakan ukuran keberhasilan, namun hanyalah sebagian, dan bukan segalagalanya. Selain itu, bangunan olahraga sebagai sebuah sistem bukan hanya menyangkut olahraga prestasi saja, tetapi juga olahraga rekreasi dan olahraga pendidikan. Sementara dua bangunan olahraga tersebut tidak harus berujung pada prestasi olahraga.

Keterkaitan empat dimensi dasar pembangunan olahraga, seperti partisipasi, ruang terbuka, kebugaran, dan sumber daya manusia tersebut sangat erat sekali. Satu dengan yang lainnya saling mempengaruhi dan akan bermuara kepada peningkatan atlit berprestasi di bidang olahraga. Langkah langkah dalam mewujudkan tujuan tersebut dapat ditempuh melalui beberapa tahap yaitu :

\section{a. Pemassalan}

Pembinaan dan pengembangan olahraga mengacu pada 3 jalur yaitu Olahraga Pendidikan, Olahraga Rekreasi dan Olahraga Prestasi. Olahraga Pendidikan merupakan jalur utama sebagai dasar dan proses awal dari sebuah pembinaan sangat berkaitan erat dengan upaya-upaya pengembangan olahraga yang lebih diarahkan pada pencapaian tujuan tujuan pendidikan melalui kegiatan olahraga, sehingga dapat berdampak secara langsung 
pada pengembangan kualitas sumber daya manusia di lingkungan persekolahan.

\section{b. Pembibitan / Pemanduan Bakat}

Pemanduan bakat bertujuan untuk memprediksi dengan tingkat peluang sukses yang optimal dalam rangka mengikuti dan menyelesaikan program latihan (proses) dan mencapai prestasi puncak yang ditargetkan (produk). Bakat selain berkaitan dengan manusia sebagai suatu keutuhan. Kriteria bakat dapat merinci seseorang dan melepaskan bagian-bagian penting dari kepribadiannya.

c. Pembinaan Lanjutan

Seorang atlit menjadi juara disebabkan karena adanya konvergensi antara atlit yang berbakat dan proses pembinaan yang benar, dengan perbandingan sumbangan atlet $70 \%$ dan porsi pembinaan $30 \%$. Atlit menjadi juara karena dibuat, bukan terlahir sebagai juara. Atlit yang dapat mencapai prestasi tinggi karena memiliki kemampuan memaksimalkan efisiensi fisik dan mentalnya serta kemampuan teknik dan taktiknya, beradaptasi dengan sistem, metode, dan bentuk latihan yang terorganisasi, direncanakan secara bertahap, objektif, dan berkesinambungan.

2. Peran Dinas Pemuda Olahraga dan Pariwisata (DISPORAPAR) Kabupaten Kuningan dalam Perekrutan Tenaga Keolahragaan.
Perekrutan guru olahraga dilakukan oleh pemerintah daerah melalui Badan Kepegawaian Daerah (BKD) atas usulan dari Dinas Pemuda Olahraga dan Pariwisata (DISPORAPAR). Pengangkatan guru tersebut didasarkan pada kebutuhan dan keperluan. Namun demikian jumlah guru yang di angkat menjadi pegawai negeri sipil tidak memadai bahkan dalam segi kualitas terkadang menjadi pertimbangan tersendiri.

3. Peran Dinas Pemuda Olahraga dan Pariwisata

(DISPORAPAR)

Kabupaten Kuningan dalam

Penyediaan Sarana dan prasarana

Sarana dan prasarana olahraga merupakan hal yang sangat fundamental dalam pelaksanaan olahraga, tanpa adanya fasilitas yang memadai maka atlet tidak mungkin tersalurkan bakatnya dalam latihan secara maksimal. Sejauh ini sarana prasarana yang dimiliki oleh pengurus maupun pelatih yang dipergunakan sangat minim serta tidak memenuhi standart / kualitas yang ada. Kenyataannya fasilitas, sarana prasarana yang dimiliki oleh pemerintah maupun cabang olahraga masih jauh dari kata memadai.

4. Peran Dinas Pemuda Olahraga dan Pariwisata

(DISPORAPAR) Kabupaten Kuningan dalam Pendanaan.

Sumber pendanaan keolahragaan ditentukan berdasarkan prinsip kecukupan dan keberlanjutan. Dana keolahragaan yang 
dialokasikan dari Pemerintah dan pemerintah daerah dapat diberikan dalam bentuk hibah sesuai dengan peraturan perundang-undangan.

\section{a. Faktor Potensi Daerah}

Atlit adalah seseorang yang telah melakukan pelatihan dari salah satu cabang olahraga secara kontinyu dalam waktu tertentu serta telah menunjukkan peningkatan prestasi secara terhadap. Atlit telah mulai berlatih sejak usia dini yaitu umur 8 sampai umur 10 tahun dan mencapai prestasi puncak pada umur 18 sampai umur 24 tahun.

\section{b. Faktor Kerjasama}

Pembinaan keolahragaan ini tidak dapat lagi ditangani secara sepihak, dan ini melibatkan dari beberapa elemen yang sinergis, terarah dan mempunyai tujuan yang sama. Penggalangan sumber daya keolahragaan dilakukan melalui pembentukan dan pengembangan hubungan kerja para pihak terkait secara harmonis, terbuka, dan saling memahami keberadaan masing masing.

\section{SIMPULAN}

Hasil penelitian di lapangan, tergambar pada peran yang telah dilakukan terutama pada sistem pembinaan, perekrutan tenaga keolahragaan terutama terhadap guru olahraga sebagai guru dan pelatih, penyediaan sarana dan prasarana yang kurang memadai serta keterbatasan sumber dana yang dialokasikan untuk penyelenggaraan keolahragaan. Lebih lanjut peran yang sudah dilakukan sebagai berikut:

a. Peran dalam sistem pembinaan
Sistem pembinaan pemassalan olahraga tersebut akan diperoleh minat dan bakat seseorang, bakat yang dimiliki anak secara alami tidak merata pada sekolah yang telah dikondisikan, bahkan ada siswa yang berbakat terdapat di daerah/sekolah yang jauh dari jangkauan sehingga pembinaan yang diberikan tidak maksimal.

b. Peran dalam perekrutan tenaga

keolahragaan

Dengan minat dan bakat yang kuat sebagai potensi pembinaan, seharusnya ditunjang dengan adanya tenaga pelatih atau guru olahragayang terampil, berdedikasi dan berkualitas.

c. Peran dalam penyediaan sarana prasarana

Peralatan maupun sarana prasarana yang dimiliki baik oleh dinas pemuda olahraga dan pariwisata kabupaten kuningan, pemerintah daerah maupun swasta, sangat minim jika dibandingkan dengan jumlah calon atlit yang akan menggunakan dan prasarana sebagai media meningkatkan prestasi.

d. Peran dalam penyediaan sumber dana

Pemerintah bertanggungjawab atas penyelenggaraan keolahragaan di daerah sesuai dengan undang undang sisten keolahragaan nasional (skn), nomor : 03 tahun 2005, seharusnya menjadi dasar eksekutif - legislatif dalam menentukan dan mengalokasikan anggaran, dengan mempertimbangkan bahwa pembinaan yang dilakukan merupakan pembangunan manusia yang sehat jasmani, rohani serta berprestasi.

Untuk kelangsungan pembinaan dan pengembangan olahraga dalam meningkatkan prestasi, saran yang dapat disampaikan dalam skala prioritas, yakni :

a. Kualitas sumber daya manusia

Agar memadai baik jumlah maupun kualitas, perlu adanya peningkatan mutu melalui pendidikan, latihan maupun penataran pelatih dan wasit serta tenaga keolahragaan lainya sehingga mempunyai 
pengalaman pengelolaan dan managemen keolahragaan.

b. Komplek latihan.

Idealnya, dalam peningkatan prestasi olahraga perlu adanya pemusatan latihan (training camp) dalam format sport centre ini dimiliki oleh kabupaten kuningan, didasarkan prestasi yang diraih dan dijadikan sebagai olahraga unggulan.

c. Sistem pembinaan intensif

Kurikulum pendidikan di sekolah dalam pelajaran olahraga dibedakan menjadi dua (2) yaitu intrakurikuler dan ekstrakurikuler. Intrakurikuler dijalankan dengan tujuan meningkatkan derajat kebugaran bagi siswa. Sedangkan ekstrakurikuler dilakukan untuk menyalurkan bakat dan minat

\section{d. Anggaran}

Hal yang tak bisa dipisahkan dari pembinaan adalah penghargaan kepada mereka yang telah berkorban baik tenaga, waktu, bahkan biaya dalam proses latihan. Penghargaan yang memadai terhadap pengabdian dan perjuangan mereka menjadikan mereka lebih manusiawi, tidak terkesan habis manis sepah di buang.

\section{DAFTAR PUSTAKA}

Abdul Gafur, 1983.Pidato Sambutan Hari Olahraga Nasional ( HAORNAS) I di Solo

Abdul Wahab. 2009, Analisis Kebijakan Publik. Yogyakarta: Gajah Mada University

Arikunto, Suharsimi. 1998. Prosedur Penelitian, Suatu Pengantar Pendekatan Praktek. Jakarta: Rineka Cipta

Dunn, William N. 1998. Pengantar Analisis Kebijakan Publik Edisi Kedua. Yogyakarta: Gajah Mada University Press.

Direktorat Pendidikan Dasar dan Menengah - Kantor Kementerian Pemuda dan Olahraga, 2000,
Pembinaan Olahraga Usia Dini, Jakarta. Bagian Proyek Dikdasmen.

Tachjan.H 2006. Implementasi kebijakan Publik. Bandung: AIPI BANDUNG

- PUSLIT KP2W LEMLIT UNPAD

Harsono, 1988, Teori Kepelatihan Olahraga Yayasan STO, Yogyakarta.

Harre, D. 1982, Prinsiples of Sport, Training Sports, Verlag Berlin

Islamy, Irfan. 2000. Prinsip-prinsip Perumusan Kebijakan Negara. Jakarta. Bumi Aksara. Lembaga Andimistrasi Negara, 2002, Kajian Kebijakan Publik.

Litbang KONI Pusat, 2004. Struktur Berprestasi Tinggi. Jakarta: Penerbit Pusat Penataran Litbang KONI Pusat.

Maksum, A dkk. 2004. Pola Partisipasi Masyarakat dalam berolahraga. Jalarta: Ditjen Olahraga

Moleong, Lexy J. M.A. 2001. Metodologi Penelitian Kualitatif. Bandung: Remaja Rosdakarya.

Winarno, Budi. 2002. Teori dan Proses Kebijakan Publik. Jakarta: PT. Media Presindo.

Mutohir, Toho Cholik, Sport Development Index: Konsep, Metodologi, dan Aplikasi, Kementerian Negara Pemuda dan Olahraga RI, Jakarta, 2007

Noeng, Muhadjir. 1996. Metodologi Penelitian Kualitatif Edisi III. Yogyakarta: Rake Sarasin.

Purnomohadi, 2003. Prasarana Olahraga Untuk Menyongsong Hari Depan Olahraga di Indonesia. Dalam Haszuki (ED) Perkembangan Olahraga Terkini Kajian Para 
Pakar. Jakarta: PT. Raja Grafindo Persada.

Salim, Agus. 2006. Teori dan Paradigma Penelitian Sosial, Buku Sumber Penelitian Kualitatif. Yogyakarta: Tiara Wacana.

Sugiyono.2005. Memahami Penelitian Kualitatif. Bandung: Alfabeta

Undang Undang Nomor 3 Tahun 2005 tentang Sistem Keolahragaan
Nasional, Kementerian Negara Pemuda dan Olahraga RI, Jakarta, 2005.

Undang-Undang Nomor 20 Tahun 2003 Tentang Sistem Pendidikan Nasional.

Undang Undang RI, 1999.Undang-undang Nomor 32 Tahun 2004, Tentang Pemerintahan 